\title{
IMPROVEMENT OF PROJECT RISK ASSESSMENT METHODS OF IMPLEMENTATION OF AUTOMATED INFORMATION COMPONENTS OF NON-COMMERCIAL ORGANIZATIONAL AND TECHNICAL SYSTEMS
}

\author{
Alexander Androshchuk \\ Educational and Scientific Institute of Management Training ${ }^{1}$ \\ asa_20_1968@ukr.net \\ Serhii Yevseiev \\ Department of Cyber Security and Information Technology \\ Simon Kuznets Kharkiv National University of Economics \\ 9-A Nauky ave., Kharkiv, Ukraine, 61166 \\ serhii.yevseiev@hneu.net
}

Victor Melenchuk

Department of repair and operation of automotive and special equipment Military Academy (Odessa)

10 Fontanskaya road str., Odessa, Ukraine, 65009

viktor.melenchuk1976@i.ua

Olga Lemeshko

Department of English

lemeshkolia@ukr.net

Vladimir Lemeshko

Department of Border Guard Tactics ${ }^{1}$

lem-73@ukr.net

${ }^{1}$ National Academy of the State Border Guard Service of Ukraine named after Bohdan Khmelnytskyi 46 Shevchenko str., Khmelnitsky, Ukraine, 29007

\begin{abstract}
The results of a study using the methodological apparatus of the theory of fuzzy logic and automation tools for analyzing input data for risk assessment of projects for the implementation of automated information components of organizational and technical systems are presented. Based on the model of logistics projects for motor transport units, the method for assessing the risks of projects implementing automated information components of non-commercial organizational and technical systems has been improved. To do this, let's analyze the peculiarities of implementing ERP projects as commercial ones and investigate the specifics of the activities of state institutions, when successful tasks, and not economic indicators, lay the foundation for the assessment. It is considered that it is possible to formulate a system of risk assessment indicators for reducing the effectiveness of projects for implementing automated information systems in non-commercial organizational and technical systems. A meaningful interpretation of the fuzzy approach is carried out regarding the formalization of the risk assessment process for projects of automated information systems of public institutions. A tree of fuzzy inference is constructed based on the results of a study of the description of indicators and expert assessments on the risk assessment of the implementation of the project of such an automated information system.

The improved method differs from the known ones by the use of hierarchical fuzzy inference, which makes it possible to quantify, reduce the time to evaluate project risks and improve the quality of decisions. An increase in the number of input variables leads to an increase in complexity (an increase in the number of rules) for constructing a fuzzy inference system. The construction of a hierarchical system of fuzzy inference and knowledge bases can reduce complexity (the number of rules). The development of a software module based on the algorithm of the method as part of corporate automated information systems of non-commercial organizational and technical systems will reduce the time for risk assessment of projects for the implementation of automated information systems.

Keywords: organizational and technical system, implementation project, risk management, fuzzy logical conclusion.
\end{abstract}




\section{Introduction}

The development of the state and society involves solving the issue of improving the quality of tasks by organizational (socio) technical systems (hereinafter referred to as OTS) that are part of them. Including these are the following systems: unit management, logistics, personnel learning (training), etc. A significant role in solving this question is given to informatization - the implementation of automated information systems (hereinafter - AIS). An analysis of activities over the past decade indicates that project-oriented OTSs are becoming more effective with respect to vertically integrated OTSs with their functional organization of activities [1-3]. Therefore, the current period of OTS development is characterized by a transition to a project-oriented management principle. At the same time, the activities of most OTSs have certain specifics, when the main criterion for the implementation of AIS is successfully completed tasks, and not economic indicators. For example, implementation projects of AIS material and technical support of state institutions are non-commercial in nature. The activities of most of them have significant elements of uncertainty and danger. The functioning of military and law enforcement agencies is generally impossible without risk. Therefore, one of the most important elements of project management of the implementation of AIS of such OTSs is risk management [4, 5]. Existing approaches to risk management in projects, including their assessments, are defined in the following standards: AS/NZS 4360:2004, COSO-ERM, ISO 26500:2012, FERMA, PMBoK, P2M, PRINCE, PSPRM, RMI and the like. They describe risk management approaches in projects related to financial, economic, technical systems, etc., as a rule, in deterministic and stochastic conditions. However, the management and risk assessment of AIS projects in the activities of such non-commercial (specific) OTS included in state institutions is carried out in conditions of uncertainty. As a result, most of these projects are a failure. Therefore, the improvement of the method of risk assessment of AIS projects of non-commercial OTS and the like is an urgent scientific and applied task.

The general problems of the project management study are the subject of [6]. It addressed the general issues of project management, which, as a rule, did not take into account the specifics of nonprofit OTS and similar systems. The issue of developing risk management methods in projects is presented in the following works: [7] - an organizational model for project risk management is developed while assessing project risks in the face of uncertainty; no attention is paid; [8] - a method for managing the cost of projects of scientific institutions taking into account risks has been developed, while a qualitative risk assessment is not carried out; [9] - classification of deviations in projects with respect to risks, problems, changes; [10] - methods for structuring, evaluating, and controlling project risks have been developed for the efficient implementation of projects by the enterprise at minimal cost. At the same time, in the considered works, a quantitative risk assessment of the AIS implementation projects in particular and in general other projects under conditions of uncertainty was not given attention. In [11], the Accelerated SAP Methodology (ASAP) is considered, which was developed by SAP in order to improve the implementation of information systems risk management. In [12], general issues of risk management are considered. The paper [13] presents a model for assessing the risks of logistics projects for motor units of the Armed Forces of Ukraine using three linguistic variables, taking into account the conditions of uncertainty, but it is clearly not enough to evaluate complex projects.

It should be noted that the most common approach to the implementation of commercial AIS can be considered the implementation of an ERP system, therefore, to improve the risk assessment method for projects implementing AIS of nonprofit OTS, let's consider in more detail the features of ERP implementation [14].

"ERP is an AIS implementation technology, it contains a set of coordination, organizational, investment, economic, analytical and research, information technology and production activities, the purpose of which is to inform the organization, increase the effect and optimize the management of its resources" [15].

To assess the risks of projects implementing a logistics AIS (implementation of ERP systems) of OTS to reduce the effectiveness (not achieving the desired efficiency) of a project or a project failure when implementing a project is quite problematic due to its complexity. This is due to the fact that, for example, the risks of logistic automated information system (hereinafter referred 
to as LAIS) logistics projects are characterized by a system of indicators that are usually weak and informal. These indicators reflect the ratio of the effect and costs of the project from the point of view of its participants.

Most scientists most often use the types of risk analysis and assessment that can be applied to the implementation of the AIS material and technical support of the OTS with the corresponding indicators [14-17]:

1) standard according to the method in investment analysis (Cost Benefit Analysis - CBA);

2) Activity Based Costing $(\mathrm{ABC})$ - a method that performs a functional analysis of expenses;

3) set of methods in the analysis that use integrated service planning and planning of the information sphere;

4) methods, carrying out a system analysis of the project;

5) methods of expert assessment (methods of "experience, intuition of brainstorming"), etc.

When assessing the risk of projects regarding the achievement of benefits at certain costs in existing studies, in most cases, it is proposed to use indicators of an economic and informational nature.

The economic component is estimated using methods that take into account costs based on elements of economic analysis. "One of the methods of economic risk analysis for the implementation of ERP-system projects is the so-called ABC (Activity Based Costing) - a functional-cost analysis, in the framework of which differentiated calculation and distribution of the costs of operating the system are carried out by type of activity, product and organization functions. The application of this approach involves the use of a system of financial indicators [17].

The given indicators and methods constitute the traditional existing and used set of risk assessment methods for reducing the effectiveness of implementation projects of commercial OTS.

Given the specifics of the activities of nonprofit OTS, these approaches (indicators and methods) can't be considered as comprehensive in assessing the risks of implementation projects of AIS of state institutions. Effectively they can be used only in combination, when the elements of one of the approaches allow to overcome the shortcomings in others.

The aim of the article is to substantiate an approach to improve the risk management efficiency of non-commercial OTS implementation AIS projects based on the improvement of the risk assessment method for such projects.

To achieve this goal it is necessary to solve the following tasks:

- explore methods for assessing the risks of AIS implementation projects;

- improve the method of assessing the risks of AIS implementation projects;

- practically introduce and experimentally test the improved method.

2. The method of risk assessment of projects for the implementation of automated information components of non-commercial organizational and technical systems

Below is a method for assessing the risks of AIS implementation projects using the example of a public institution AIS implementation project based on the model presented in [13]. One of the promising projects for providing OTS, which will allow a significant positive effect, is the AIS implementation. This postulate allows to formulate a system of indicators for assessing the risks of reducing the effectiveness of the implementation of AIS of non-commercial OTS (state institutions):

1) total costs of the projects and the costs of completing tasks using the project results (increase/decrease of these costs);

2) duration of the project and the duration of the tasks using the project results (increase/ decrease time);

3) quality of the performance (official) tasks;

4) effectiveness (effect) of the project and the like.

The initial data for assessing the risk of a decrease in the effectiveness of AIS implementation projects (for example, material and technical support for state institutions) is poorly formalized, so adequate tools should be used. For this, an approach is proposed that is presented in [18-20] and developed and tested in [21] and others. 
An approach is proposed to improve the method of risk assessment of implementation projects of AIS of non-commercial OTS, providing for this (Fig. 1). In the process of a qualitative assessment of project risks, it is necessary, if possible, to determine as many different indicators as possible.

\begin{tabular}{|c|c|c|}
\hline $\begin{array}{l}\text { Risk identification, } \\
\text { calculation of initial data } \\
\text { for project risk } \\
\text { assessment }\end{array}$ & $\begin{array}{c}\text { Definition of risk } \\
\text { assessment indicators of } \\
\text { implementation projects } \\
\text { of AIS of non-commercial } \\
\text { OTS }\end{array}$ & $\begin{array}{l}\text { The selection of } \\
\text { indicators that have } \\
\text { the highest rating }\end{array}$ \\
\hline $\begin{array}{l}\text { Building a tree of input } \\
\text { linguistic risk variables } \\
\text { for the AIS project }\left(a_{i}\right)\end{array}$ & $\begin{array}{c}\text { Project risk assessment } \\
\text { using hierarchical fuzzy } \\
\text { inference }\end{array}$ & $\begin{array}{l}\text { Obtaining a project risk } \\
\text { assessment result (b), } \\
\text { risk management }\end{array}$ \\
\hline
\end{tabular}

Fig. 1. Scheme of an improved method of risk assessment of projects for the implementation of automated information systems of non-commercial organizational and technical systems

In addition, the essence of the proposed improvement of the method is to obtain and compare indicators that determine various aspects of the activities and effectiveness of the OTS automated information system. In this case, an expert assessment of their predicted values after the implementation of the project is applied.

Formal interpretation of the risk assessment of AIS projects is necessary for a meaningful interpretation of the fuzzy approach. First of all, it involves the activities of the researcher in the selection of input and output linguistic variables of the fuzzy logical inference system that is being developed. Each input variable should influence the final result. For example, the level of the indicator for increasing the volume of performance of official tasks $-a_{1}$.

Obviously, the higher the score, the more attractive the project is, and the risks are small. The output variable $b$ is formalized as the risk level for the implementation of the AIS project of non-commercial OTS. To do this, let's construct a tree of fuzzy inference based on the results of a study of a description of indicators and expert assessments on the risk assessment of the implementation of the AIS project, for example

1) $a_{1}$ - success indicators:

$a_{11}$ - indicator of the success of the project as a whole (the project is completed on time, within the budget and with a positive effect);

2) $a_{2}$ - performance indicators of individual (service) tasks:

$a_{21}$-indicator of the volume of completed tasks;

$a_{22}$ - indicator of the share of qualitatively completed tasks;

$a_{23}$-indicator of the share of completed tasks on time;

3) $a_{3}$ - performance indicators:

$a_{31}$ - time for the implementation of the project;

$a_{32}$ - time for organizational activities for the implementation of the project (installation and trial operation of the AIS, time for making complaints, time for staff training, etc.);

$a_{33}$ - time to complete tasks using the project results;

4) $a_{4}$ - expense indicators:

$a_{41}$-indicator of the cost of implementing the project;

$a_{42}$ - indicator of personnel costs;

$a_{43}$ - indicator of the cost of completing tasks and paperwork.

For this case, 10 input variables are selected. For other cases, the number and content of input variables may be different.

Let $b$ denote the result of the risk assessment of the implementation of the AIS project. The initial variable is the level of risk of reduced efficiency (failure to achieve the desired effectiveness) of AIS projects - $b$ : management efficiency, staff training level, provision efficiency, and the like.

In the improved method of fuzzy inference regarding the assessment of the risk of reduced efficiency (failure to achieve the desired effectiveness) of the AIS implementation project, all vari- 
ables are linguistic in nature with a universal set $M_{u}=\left\{m_{1}, m_{2}, \ldots m_{n}\right\}$. According to [13], these variables can be measured in the range of numbers from 0 to 10 or in the range from 0 to 1 by participants project based on their knowledge and experience. As a term-set of input and output variables, for simplification it is proposed to use the set $L_{1}=$ '“low", "medium", "high"\} (level) of the variable. The construction of the membership functions of the terms, which is suggested for linguistic variables can be carried out using various methods, including the method of statistical processing of expert information, which is proposed in [19].

Next, it is necessary to build a fuzzy knowledge base (hereinafter - KB). The implementation of the task of assessing the risk of LAIS implementation projects (reducing efficiency, not achieving the desired LAIS project effectiveness) requires a significant number of rules $\left(R=10^{3}=1000\right)$, which complicates the use of fuzzy inference (perception, editing and use). This situation is solved by constructing a hierarchical knowledge base [18] - a breakdown of a complex logical inference into several simple logical conclusions. This is facilitated by the hierarchical structure of the process of non-commercial OTS (state institutions). A hierarchical representation of the input variables and the construction of a "tree" of output are necessary, which defines a system of lower-dimensional knowledge statements embedded in each other. Such a tree is proposed for fuzzy inference after 10 input variables (Fig. 2).

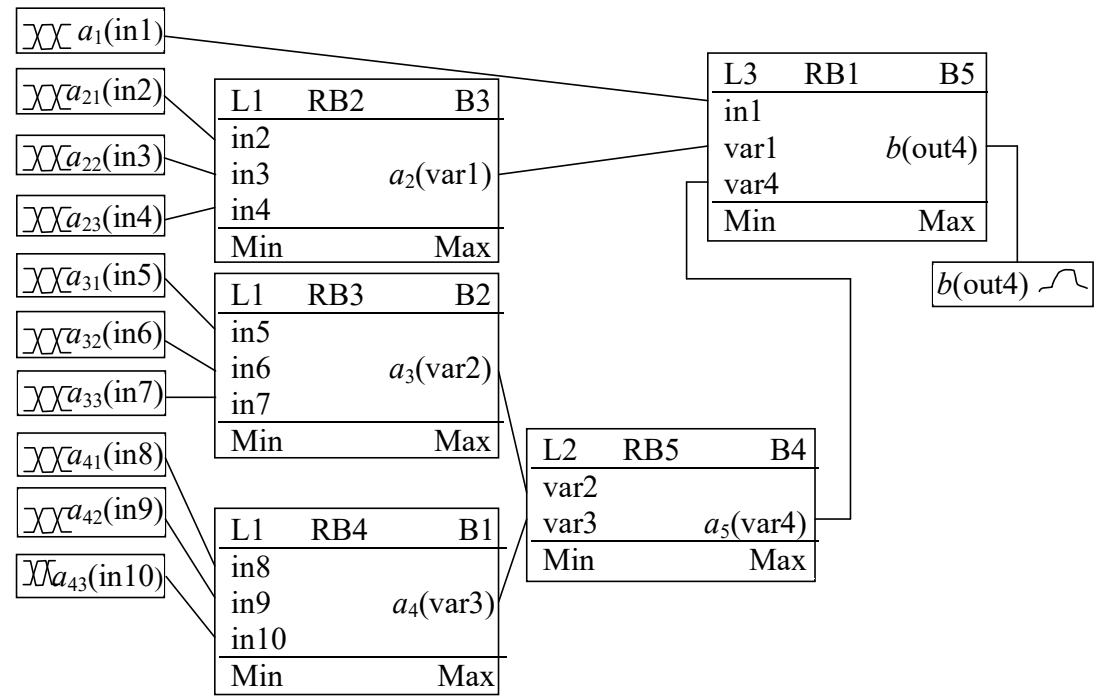

Fig. 2. The system of fuzzy hierarchical derivation of risk assessment of the implementation of projects of automated information systems in the notation of the program fuzzyTech 6.0

Applying the hierarchical structure of fuzzy inference, one can take into account a significant number of input variables that affect the overall risk assessment of AIS implementation projects. These projects are not a permanent system, so the number and content of input variables can vary. At the same time, the knowledge of experts (project participants) is changing.

According to [13], for each level of fuzzy inference, the activation method is min. This is due to the fact that all the rules as a logical connection for a subcondition apply only a fuzzy conjunction (operation "AND"). As a result, the aggregation method provides for the use of the min-conjunction operation. The accumulation of rule endings uses max-disjunction. As a defuzzification method, various approaches can be applied, for example, the center of gravity method, which has proven itself well.

Another advantage of the hierarchical fuzzy inference is the absence of defuzzification operations and fuzzification for the intermediate variables $a_{2}, a_{3}, a_{4}$ and $a_{5}$ (Fig. 2). This is due to the fact that the intermediate result of fuzzy inference in a certain form is direct to the machine of fuzzy inference of the next level of the system. As a result, to describe intermediate variables in hierarchical fuzzy knowledge bases, it is sufficient to specify only term sets; membership functions are not required. 


\section{Implementation and experimental evaluation of the method}

The implementation of the method of risk assessment of the implementation projects of non-commercial AIS based on hierarchical fuzzy inference was carried out using the fuzzyTech 6.0 package. For a set of input variables, the value of the output variable $b$ was not once calculated. The obtained results coincide with the intuitively obtained ones. For some of the data sets, the risk is quite high, therefore, additional measures are required to manage risks or cancel this version of the project in general.

The adequacy of the improved method for assessing the risks of non-commercial AIS implementation projects is verified using experiments conducted by the authors on various non-commercial OTSs. So in [21] and [22] it is carried out it with respect to the OTS for the management of law enforcement units; in [23], this is carried out in relation to systems for teaching students and students in a foreign language.

Let's consider in more detail the experiment conducted by V. Melenchuk [13] on the basis of the Department of Repair and Maintenance of Automotive and Special Equipment of the Military Academy (Odesa). For the experiment, let's select data on the use of AIS logistics, which occurred during the performance of official tasks at different times. During the experiment, the following project risk indicators are evaluated: the time that is spent on project risk assessment; the quality of the decision - the risk assessment coincides with the known (correct decision), the assessment does not match (incorrect decision).

The results of the time experiment for risk assessment are presented in Fig. 3, $\boldsymbol{a}$ by the quality of decisions made - in Fig. $3, \boldsymbol{b}$.

The results of the experiment indicate that the program module "Project Risk Assessment", which implements an improved method for assessing the risks of AIS projects of material and technical support of motor units of state institutions, provides the opportunity:

- reduce the time for project risk assessment by 1.23 times and increase the reliability of decisions by 1.68 times in comparison with the implementation of the project risk assessment in a "manual" way;

- reduce the time to evaluate the project risk by 1.14 times and increase the reliability of project management decisions by 1.32 times compared with the use of another method.

The development of a software module based on the algorithm of the method as part of automated information systems of government institutions will reduce the time to assess the risks of AIS implementation projects.
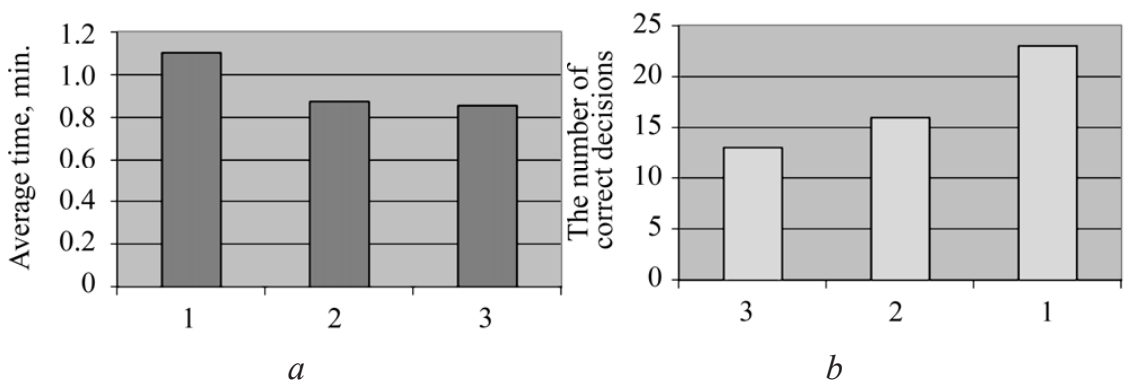

Fig. 3. The results of the experimental verification:

1 - "manual" method; 2 - automation (statistical approach); 3 - automation (developed approach); $a$ - verification of time for risk assessment, $b$ - verification of the quality of decisions

\section{Discussion of research results}

The studies presented in the article are primarily theoretical-analytical in nature, based on the results of experiments described in the available literature. The improved method for assessing the risks of AIS implementation projects is the basis for improving the risk management method of AIS implementation projects.

The basis of improvement is the use of hierarchical fuzzy inference. Let's believe that this study is an extension of its application in a new subject area - project risk assessment. The ad- 
equacy of this approach is confirmed by other studies in other subject areas when it comes to weak formalization or not the possibility of formalization in general. In most cases, the situation is complicated by uncertainty. As a result, the application of the apparatus of probability theory and mathematical statistics here gives the worst results.

However, it should be noted that the use of fuzzy logic apparatus requires the creation of additional components as part of the OTS:

a) unit that carries out a number of actions to perform the fuzzy logic algorithm (working with statistics, working with knowledge, building a fuzzy inference system, etc.);

b) presence of highly qualified personnel in the field of mathematics, analytics and work with knowledge and the like;

c) construction in OTS of a system for formalizing, accumulating, processing and applying statistical data, knowledge, and the like.

\section{Conclusions}

So, the article presents an improved method for assessing the risks of the implementation of AIS for non-commercial OTS by the example of a study of the projects for introducing AIS of material and technical support for motor units of state institutions. It is found that:

a) the apparatus of probability theory and mathematical statistics does not allow to assess the risks of projects for the implementation of automated information systems of non-commercial OTS, the activities of which are carried out in conditions of uncertainty;

b) improved method differs from the known ones by using a hierarchical fuzzy inference system. An increase in the number of input variables leads to an increase in complexity (an increase in the number of rules) for constructing a fuzzy inference system. The construction of a hierarchical system of fuzzy inference and knowledge bases can reduce complexity (the number of rules);

c) the method makes it possible to quantify, reduce the time to assess the risks of projects and improve the quality of decisions on projects for the implementation of AIS of non-commercial OTS. The practical implementation of an improved method requires the development of new or adaptation of existing methods of working with explicit and implicit knowledge. It is also necessary to formalize the experience gained by experts, in which all project participants (developers, users, etc.) can be involved, is the prospect of further research in this direction;

d) studies are given that can be developed to assess the risk of other projects and the entire class of automated information systems of the OTS in the face of uncertainty.

\section{References}

[1] A Guide to the Project Management Body of Knowledge (PMBOK® Guide) (2017). Project Management Institute, 760.

[2] Chimshir, V. (2013). Matters of projects classification and ranking by applicable technical systems. Eastern-European Journal of Enterprise Technologies, 5 (2 (65)), 44-48. Available at: http://journals.uran.ua/eejet/article/view/18441/16180

[3] Altwies, D., White, D. (2018). Achieve PMP Exam Success: A Concise Study Guide for the Busy Project Manager. J. Ross Publishing, 526.

[4] Microsoft Solutions Framework. Distsiplina upravleniya riskami MSF ver. 1.1. Available at: https://www.microsoft.com/ru-ru

[5] DeMarko, T., Lister, T. (2005). Val'siruya s medvedyami: upravlenie riskami v proektah po razrabotke programmnogo obespecheniya. p.m Office, 190.

[6] Ageev, A. E. (2006). Modelirovanie organizatsionnyh struktur i protsessov upravleniya riskami proekta. Otkrytye informatsionnye i komp'yuternye integrirovannye tehnologii, 32, 110-113.

[7] Bedriy, D. I., Polshakov, V. I. (2012). Research projects budgeting with an allowance for risks. Eastern-European Journal of Enterprise Technologies, 1 (12 (55)), 47-49. Available at: http://journals.uran.ua/eejet/article/view/3626/3399

[8] Danchenko, O. B. (2014). Ohliad suchasnykh metodolohiy upravlinnia ryzykamy v proektakh. Upravlinnia proektamy ta rozvytok vyrobnytstva, 1, 16-25.

[9] Latkin, M. A. (2008). Informatsionnaya model' upravleniya riskami proektov predpriyatiya. Otkrytye informatsionnye i komp'yuternye integrirovannye tehnologii, 39, 210-214.

[10] Fillips, D. (2006). Upravlenie proektami v oblasti informatsionnyh tehnologiy. Moscow: Lori, 374.

[11] Bushuev, S. D., Yaroshenko, N. P., Yaroshenko, Yu. F. (2013). Upravlenie proektami i programmami razvitiya organizatsiy na osnove predprinimatel'skoy energii. Upravlenie proektami i programmami, 4, 300-311. 
[12] Head, G. L., Horn, I. I. (1994). Essentials of Risk Management. Insurance Institute of America, 230.

[13] Melenchuk, V. M. (2016). Model of Risk Assessment in Transport Logistic Projects / Programs / Portfolios Using Fuzzy Inference. Visnyk Lvivskoho derzhavnoho universytetu bezpeky zhyttiediyalnosti, 13, 48-55.

[14] Pleskach, V. L., Zatonatska, T. H. (2011). Informatsiyni systemy i tekhnolohiyi na pidpryiemstvakh. Kyiv: Znannia, 718.

[15] Ganesh, K., Mohapatra, S., Anbuudayasankar, S. P., Sivakumar, P. (2014). Enterprise Resource Planning: Fundamentals of Design and Implementation. Springer, 170. doi: https://doi.org/10.1007/978-3-319-05927-3

[16] Rybydailo, A. A., Poryvai, O. V., Levshenko, O. S. et. al. (2015). Analiz zarubizhnoho ta vitchyznianoho dosvidu upravlinnia proektamy z vprovadzhennia informatsiynykh tekhnolohiy. Zbirnyk naukovykh prats Tsentru voienno-stratehichnykh doslidzhen Natsionalnoho universytetu oborony Ukrainy imeni Ivana Cherniakhovskoho, 1 (53), 55-64.

[17] Davis, W. S., Yen, D. C. (1998). The Information System Consultant's Handbook: Systems Analysis and Design. CRCPress, 800

[18] Leonenkov, A. V. (2005). Nechetkoe modelirovanie v srede MatLab i FuzzyTECH. Sankt-Peterburg: BHV-Peterburg, 736.

[19] Shtovba, S. D. (2007). Proektirovanie nechetkih sistem sredstvami MatLab. Moscow: Goryachaya liniya-Telekom, 288.

[20] Cao, B.-Y. et. al. (Eds.) (2014). Fuzzy Systems \& Operations Research and Management. Springer, 402.

[21] Androshchuk, O. S., Mykhailenko, O. V. (2014). Model vyiavlennia porushnykiv zakonodavstva na derzhavnomu kordoni iz zastosuvanniam ierarkhichnoho nechitkoho lohichnoho vyvodu. Suchasni informatsiyni tekhnolohiyi u sferi bezpeky ta oborony, 1, 5-10.

[22] Lemeshko, V. (2016). The usage of border units for specific tasks: retrospective analysis and development prospects. Zbirnyk naukovykh prats Natsionalnoi akademiyi Derzhavnoi prykordonnoi sluzhby Ukrainy. Seriya: viyskovi ta tekhnichni nauky, 4 (70), 101-117.

[23] Lemeshko, O. V., Yankovets, A. V., Bets, I. O., Isaieva, I. F. (2019). Peculiarities of the English Language Training of Military Administration Masters. Revista Romaneasca Pentru Educatie Multidimensionala, 11 (2), 160. doi: https://doi.org/10.18662/ $\operatorname{rrem} / 123$

Received date 16.12.2019

Accepted date 24.01.2020

Published date 31.01.2020
(C) The Author(s) 2020

This is an open access article under the CC BY license (http://creativecommons.org/licenses/by/4.0). 